\title{
Food intake and energy expenditure of army recruits
}

\author{
By O. G. EDHOLM, J. M. ADAM,* M. J. R. HEALY, $†$ H. S. WOLFF, $\rfloor$ \\ R. GOLDSMITH§ AND T. W. BEST\| \\ Division of Human Physiology, National Institute for Medical Research, \\ London $\mathrm{NW}_{3}$
}

(Received I3 April r970-Accepted I Fune 1970)

\begin{abstract}
I. The food intake of sixty-four infantry recruits was measured at six centres during 3 weeks of initial training. The daily energy expenditure was measured in thirty-five of these men.

2. The mean daily consumption of the sixty-four subjects provided them with $3850 \mathrm{kcal}$ $(\mathrm{I} 6 \mathrm{I} 1 \circ \mathrm{kJ})$; the energy expenditure of the thirty-five subjects averaged $3750 \mathrm{kcal}(\mathrm{r} 5690 \mathrm{~kJ})$.

3. Serial auto- and cross-correlations of intake and expenditure were very small and there was no significant relationship between food intake and energy expenditure on the same day.

4. The intakes and expenditures of different subjects at the same centre were not independent.

5. There was a significant relationship between intake and expenditure for the whole period of the survey when results for all subjects were included. In three centres the correlation was high, $+0.788(P<0.001)$, but was only $+0.083(P<0.5)$ in the remaining three centres.

6 . There was a positive but not significant correlation between body-weight and the average food intake of $6 \mathrm{~d}$.

7. There was a negative correlation between body-weight and calorie balance.

8. Weight change and calorie balance over I week were related, the correlation averaging $0 \cdot 40$. There was a correlation of 0.32 between daily weight changes and calorie balance. A rather small amount of variation in calorie balance can be explained by contemporary changes in weight.
\end{abstract}

The assessment of calorie balance in man requires the measurement of food intake and energy expenditure. Food intake has been assessed by many workers in a variety of ways, but the most accurate technique is to weigh all food provided for the individual subject, weighing quantities not consumed, and then to determine the composition of food consumed. The technique is laborious but has been carried out in a number of surveys (Edholm, Fletcher, Widdowson \& McCance, 1955; Garry, Passmore, Warnock \& Durnin, I955; Durnin, Blake \& Brockway, r957; Durnin \& Brockway, I959; Consolazio, Hawkins, Johnson \& Friedemann, 1959). Energy expenditure is usually estimated by timing all activities, measuring oxygen consumption over $5^{-20}$ min while the subject is engaged in a specific activity, and computing the total expenditure from these figures. Durnin \& Brockway (1959) have described the various errors, which include faulty recording of activity, inexact definition of activity, difficulties of measuring the metabolic cost of an activity, and lack of correspondence between activity measured and that recorded in the timed activity. Many of these errors could be avoided

* Present address : Department of Applied Physiology, Royal Army Medical College, London, SW r. + Present address: Division of Computing and Statistics, Clinical Research Centre, Watford Road, Harrow, Middx.

† Present address: Division of Biomedical Engineering, National Institute for Medical Research, London $\mathrm{NW}_{3}$.

$\S$ Present address: Medical School, University of Nottingham.

I| Present address : Officer Training Wing, Army School of Catering, St Omer Barracks, Aldershot. 
if continuous measurement of oxygen consumption throughout the day were feasible. The apparatus available includes the Douglas bag and the Max Planck Respirometer. Both of these are liable to interfere with some vigorous activities and cannot be worn continuously. The introduction of the integrating motor pneumotachograph (IMP) by Wolff (1958) has made it possible to measure oxygen consumption over long periods of time without interference with activities. Since a face mask has to be worn with

Table $\mathrm{x}$. Initial age, height and weight of the subjects

\begin{tabular}{|c|c|c|c|c|c|c|c|c|c|c|c|}
\hline \multirow[b]{2}{*}{ Centre } & \multirow[b]{2}{*}{$\begin{array}{c}\text { Subject } \\
\text { no. }\end{array}$} & \multicolumn{2}{|c|}{ Age } & \multirow[b]{2}{*}{$\begin{array}{l}\text { Height. } \\
\text { (cm) }\end{array}$} & \multirow[b]{2}{*}{$\begin{array}{l}\text { Weight } \\
(\mathrm{kg})\end{array}$} & \multirow[b]{2}{*}{ Centre } & \multirow[b]{2}{*}{$\begin{array}{c}\text { Subject } \\
\text { no. }\end{array}$} & \multicolumn{2}{|c|}{ Age } & \multirow[b]{2}{*}{$\begin{array}{l}\text { Height } \\
(\mathrm{cm})\end{array}$} & \multirow[b]{2}{*}{$\begin{array}{c}\text { Weight } \\
\text { (kg) }\end{array}$} \\
\hline & & years & months & & & & & years & months & & \\
\hline \multirow[t]{10}{*}{ A } & I & 18 & 7 & $176 \cdot 2$ & $62 \cdot 12$ & \multirow[t]{12}{*}{$\mathrm{D}$} & I & I 8 & 9 & 166.0 & $60 \cdot 23$ \\
\hline & $2 X$ & 18 & 8 & 174.6 & $68 \cdot 50$ & & $2 X$ & 18 & 8 & $180 \cdot 5$ & $74 \cdot 12$ \\
\hline & $3 x$ & I 8 & 8 & $166 \cdot I$ & $58 \cdot 95$ & & $3 x$ & 18 & 6 & 167.0 & $6 r \cdot 38$ \\
\hline & 4 & 18 & 7 & 173.7 & $58 \cdot 83$ & & 4 & 18 & 9 & $176 \cdot 0$ & $72 \cdot 96$ \\
\hline & $5 X$ & 18 & 7 & $178 \cdot 4$ & $64 \cdot 30$ & & $5 X$ & 18 & 6 & 170.5 & $74 \cdot 18$ \\
\hline & $6 x$ & 18 & 6 & $180 \cdot 0$ & $60 \cdot 50$ & & 6 & 18 & ro & 175.5 & $62 \cdot 12$ \\
\hline & 7 & 18 & 8 & $178 \cdot 1$ & $65 \cdot 46$ & & $7 x$ & 21 & $\mathrm{I}$ & $172 \cdot 0$ & 63.06 \\
\hline & 8 & 20 & 4 & $165 \cdot I$ & $58 \cdot 51$ & & 8 & 18 & 9 & $167 \cdot 0$ & $55^{\circ} 04$ \\
\hline & $9 \mathrm{X}$ & 18 & 8 & $178 \cdot 4$ & $66 \cdot 93$ & & 9 & r9 & $\circ$ & $169 \cdot 5$ & 55.50 \\
\hline & IO & 18 & 7 & $177 \cdot 8$ & $62 \cdot 79$ & & Io $\mathrm{X}$ & $\times 8$ & 8 & $172 \cdot 0$ & $60 \cdot 80$ \\
\hline \multirow{2}{*}{\multicolumn{2}{|c|}{ Mean }} & 18 & 9 & 174.8 & 62.60 & & I I X & 18 & 8 & I $71 \cdot 5$ & $60 \cdot 10$ \\
\hline & & & 9 & & & & 12 & I 8 & 9 & I 80.0 & $73^{\circ} 7 x$ \\
\hline \multirow[t]{11}{*}{ B } & & $2 \mathrm{I}$ & 10 & 174.7 & $62 \cdot 55$ & Mean & & 18 & II & $172 \cdot 2$ & $64 \cdot 43$ \\
\hline & $2 \mathrm{X}$ & 17 & $\begin{array}{l}9 \\
9\end{array}$ & 179.5 & $62 \cdot 01$ & \multirow{12}{*}{$\mathrm{E}$} & I $\mathrm{X}$ & 19 & 10 & 176.8 & $65 \cdot 10$ \\
\hline & $\begin{array}{l}3 X \\
4 X\end{array}$ & $\begin{array}{l}18 \\
17\end{array}$ & $\begin{array}{r}9 \\
\text { I0 }\end{array}$ & $\begin{array}{l}181.5 \\
173.5\end{array}$ & $\begin{array}{l}70 \cdot 72 \\
60 \cdot 19\end{array}$ & & 2 & x 9 & 5 & $166 \cdot 7$ & 50.25 \\
\hline & $5 X$ & 18 & 9 & 167.5 & $55 \cdot 39$ & & $3 x$ & I 8 & 7 & 174.0 & $65 \cdot 38$ \\
\hline & $6 x$ & I 8 & 8 & 169.8 & $55^{\circ} 92$ & & 4 & I 8 & 7 & $173 \cdot 8$ & 66.00 \\
\hline & 7 & I 8 & 8 & 169.5 & $6 I \cdot 74$ & & 5 & 20 & 6 & $I 6 I \cdot I$ & $64 \cdot 15$ \\
\hline & 8 & $2 I$ & 4 & $164 \cdot 0$ & 54.95 & & 6 & 23 & 6 & 170.0 & $58 \cdot 28$ \\
\hline & 9 & I7 & 10 & 170.3 & $53 \cdot 01$ & & $7 X$ & 18 & IO & I $7 \times 5$ & $68 \cdot 35$ \\
\hline & Io & 17 & 9 & $179 \cdot 6$ & $59 \cdot 94$ & & 8 & 19 & I & I $68 \cdot 2$ & $57 \cdot 34$ \\
\hline & II & 17 & II & I 64.8 & $60 \cdot 82$ & & $9 \mathrm{X}$ & I 8 & 9 & $165^{\circ} \mathrm{O}$ & $72 \cdot 03$ \\
\hline & I2 & 17 & 9 & $164 \cdot I$ & 53.70 & & ro & 20 & 4 & 168.9 & $67 \cdot 25$ \\
\hline \multirow{2}{*}{\multicolumn{2}{|c|}{ Mean }} & 18 & 9 & I 71.5 & $59 \cdot 24$ & & I I & I9 & 4 & $175 \cdot 8$ & $5^{8} \cdot 70$ \\
\hline & & & & & & & 12 & I9 & 2 & $177 \circ 0$ & $82 \cdot 80$ \\
\hline \multirow[t]{11}{*}{$\mathrm{C}$} & IX & I8 & 8 & $175^{\circ} \mathrm{O}$ & 80.31 & \multicolumn{2}{|c|}{ Mean } & I 9 & 8 & 170.6 & $64 \cdot 63$ \\
\hline & ${ }^{2} x$ & $\begin{array}{l}20 \\
20\end{array}$ & $\begin{array}{l}7 \\
4\end{array}$ & $\begin{array}{l}\text { I82:2 } \\
\text { I } 64 \cdot 0\end{array}$ & $\begin{array}{l}72 \cdot 44 \\
57 \cdot 37\end{array}$ & \multirow{6}{*}{$\mathbf{F}$} & I X & 20 & I I & I $62 \cdot 3$ & $60 \cdot 00$ \\
\hline & $\begin{array}{l}3 \times \\
4\end{array}$ & 18 & $\begin{array}{l}+ \\
8\end{array}$ & 170.4 & $56 \cdot 29$ & & $2 X$ & $x 9$ & 6 & I $78 \cdot 3$ & $76 \cdot 80$ \\
\hline & 5 & $2 I$ & 4 & 172.8 & $59 \cdot 61$ & & $3 x$ & 19 & 4 & 165.6 & 66.47 \\
\hline & $6 x$ & 20 & 6 & $168 \cdot 2$ & $54 \cdot 39$ & & $4 X$ & 17 & I I & $17 x \cdot 6$ & 66.05 \\
\hline & $7 x$ & 20 & 6 & $175^{\circ} 5$ & $72 \cdot 70$ & & $5 \mathrm{X}$ & 19 & 5 & 177.6 & 63.07 \\
\hline & 8 & 18 & 7 & $176 \cdot 4$ & 66.87 & & $6 x$ & 19 & 6 & 176.8 & $62 \cdot 65$ \\
\hline & $9 X$ & 18 & 8 & $178 \cdot 0$ & $6 I \cdot 6 I$ & \multirow[t]{5}{*}{ Mean } & & 19 & 4 & 172.0 & $67 \cdot 49$ \\
\hline & IO & 18 & 8 & $172 \cdot 5$ & $55 \cdot 27$ & & & & & & \\
\hline & I I X & I 8 & 8 & $179^{\circ} 0$ & $65.9 \mathrm{I}$ & & & & & & \\
\hline & 12 & 20 & 7 & $168 \cdot 4$ & $57 \cdot 20$ & & & & & & \\
\hline Mean & & 19 & 7 & $173 \cdot 5$ & $63 \cdot 33$ & & & & & & \\
\hline
\end{tabular}

Summary of characteristics

\begin{tabular}{lcc} 
& & \multicolumn{1}{c}{ Range } \\
Age (years) & 19.2 & $17.9-23.6$ \\
Height (cm) 172.5 & $161 \cdot 1-182.2$ \\
Weight (kg) & 63.30 & $50.25-82.80$
\end{tabular}

$\mathrm{X}$, subjects using the integrating motor pneumotachograph. 
the IMP there are social limitations to its use, but in a military population these limitations are reduced. The studies reported in this paper were carried out on young recruits during their initial Army training. Since they ate in a common dining-hall and had almost identical activities they were suitable subjects in whom to study calorie balance. The observations were made at centres in different parts of England and Wales at intervals during different seasons of the year.

\section{METHODS}

\section{Subjects}

The sixty-four men were between 17.75 and 23.5 years of age. The initial height, weight and age of each subject are given in Table $I$.

\section{Procedure}

Surveys were carried out at six centres. These were chosen in an attempt to obtain a representative sample of the sixty infantry centres which existed at the time of the survey in Great Britain. Two were in a suburban area of London and one each in Yorkshire, Devon, Warwickshire and Glamorgan. In one centre six subjects were studied, in another ten subjects, and there were twelve subjects in each of the remaining four centres. The objects and methods used were explained in detail to the recruits, and $30-75 \%$ volunteered to take part. As there was always an excess number of volunteers, the Personnel Selection Officer made the final choice, selecting subjects representative of recruits at that centre.

In five surveys observations were made during the 2 nd, $5^{\text {th }}$ and $9^{\text {th }}$ weeks of the ro-week training period, and in the sixth survey observations were made in the 6th, 7 th and 8 th weeks. The week started at 06.00 hours on Monday and continued until 'lights out' on the following Sunday. The surveys were made in the following months over a period of 3 years: February-April, March-May, April-May, August-September, October-December, November-December.

\section{Measurement of energy expenditure}

Energy expenditure was measured in six of the twelve subjects at four centres, on five of the ten subjects at one centre and on all six subjects at another centre, a total of thirty-five subjects. Ventilation volume was measured and a sample of expired air obtained using the integrating motor pneumotachograph (Wolff, 1958). The IMP weighs altogether about $2.5 \mathrm{~kg}$ and consists of a face mask to which is attached a flow-meter connected to an integrating unit and sampling device. The integrating unit and sample tin were carried in a haversack on the back. The face mask was worn for periods of approximately $2 \mathrm{~h}$, with $19-20 \mathrm{~min}$ between periods, for most of the day excluding meal times. It was worn during all phases of military drill, including physical training, and during games. 


\section{Timed activity study}

A complete timed activity study was maintained throughout the day, beginning when the men were aroused in the morning and continuing until they were in bed at night. Several methods were used, depending upon the type of activity. A detailed description of methods has been given by Wolff (1959). During the greater part of the day the subjects were engaged in group activities, drill, lectures, meals and games. An observer, equipped with a walkie-talkie radio set, accompanied the group and reported all changes of activity to a mobile laboratory. The activities were recorded by means of a multichannel integrating clock (Wolff, 1959).

There were short periods when subjects could not wear an IMP or be under observation, and a diary card (Edholm et al. 1955) was used for recording details of activities.

\section{Gas analysis}

A card was attached to the sample tin of the IMP and on this were recorded the subject's name, date, dial readings at the beginning and end of the sampling period, time, activity, temperature of the expired air, barometric pressure and calibration of the IMP. The sample tin was removed to the mobile laboratory, and the gas sample transferred to Brodie bottles for subsequent analysis, using a modified Scholander apparatus. The results of the gas analyses were recorded on the card, for use together with ventilation volumes in Weins' formula, so arriving at calorie expenditure.

\section{Mobile laboratories}

A 3-ton army mobile workshop with a 2-ton trailer were converted into mobile laboratories for gas analyses, recording timed activity values and maintenance of equipment.

\section{Body-weight}

All subjects were weighed daily, immediately after arising in the morning. They were weighed nude after urinating. The balance used was calibrated at frequent intervals. Duplicate weighings agreed to within $25 \mathrm{~g}$.

\section{Basal metabolic rate}

Basal metabolic rates were measured between 05.30 and 06.30 hours. The subjects had been in bed since 22.00 hours the previous evening and had no food or drink before the measurement. A Benedict Roth apparatus was used, and the subjects were instructed in its use. All measurements were made in the barrack room before the subject had got out of bed. One measurement was made on each subject each week.

\section{Dietary survey}

Food intake of all the sixty-four subjects was measured. All the subjects ate together in the dining-hall. One or more members of the dietary team were in the kitchen throughout the preparation of meals, and a recipe form was used for all dishes. Each subject was given a reference number; he obtained his meal already 
weighed and served at the kitchen hatch, and sat at a reserved place at a special table at which an observer measured the bread, butter and tea consumed, and weighed the plate waste, separating it into its components. An observer was present in the canteen when it was open for the subjects, and he recorded all purchases and collected waste. The recruits had only a limited time when they were able to leave barracks and restaurant meals were very few. The subjects recorded such meals, together with details of beer or other drink, on a daily diary card which was checked at the end of each day. The subjects co-operated satisfactorily and also agreed to the checking and weighing of contents of food parcels. The proportion of total calories received from sources other than the canteen or dining hall was less than $3 \%$.

\section{Calculation of food intake}

The weight of food consumed and wasted was entered meal by meal on one form, and at the end of the day the total amount of food consumed was entered on a second sheet for calculation. The calorie value of the food was calculated from the tables prepared by McCance \& Widdowson (1960). Some items of food were analysed by bomb calorimetry. Details of the composition of some items such as chocolates were obtained from the manufacturers.

The factors used for conversion of nutrients into calories were $4.1,9.3$ and 3.75 for protein, fat and carbohydrate respectively. All the carbohydrate values were expressed as monosaccharides.

\section{Calculation of energy expenditure}

A time-table for each subject was drawn up each day; when IMP values were available these were entered. Timed activity figures for the rest of the day were used. Entries for energy expenditure were obtained as follows: $(a)$ measurements made on the individual subject, e.g. the measured oxygen consumption for one drill parade was used for a second similar drill; $(b)$ the measured basal metabolic rate was used for the calorie cost of sleep; $(c)$ where there were no directly applicable experimental values results obtained in previous surveys were used (Edholm et al. 1955). The energy expenditure of sedentary activities was calculated on the basis of surface area; other activities in terms of body-weight. The total energy expenditure was computed from midnight to midnight.

\section{RESULTS}

Before analysis the records were inspected and five men for whom several days' values were missing were rejected. One man at centre B had 2 missing days; two isolated values (daily intakes of 8655 and $67 \mathrm{I} \mathrm{kcal}$ ) at centre D were also omitted from the analysis (neither of these involved a subject whose energy expenditure was being measured). Conventional values to replace these were supplied as part of the statistical analysis.

\section{Food intake}

A preliminary analysis of intake was made for the thirty-four men at centres A, B and $\mathrm{C}$; at these centres all 7 days of the week were studied. Table $2 \mathrm{~A}$ gives the analysis 
of variance of the 3-week total intakes for each man (in units of a single day's intake). There is no evidence that the wearing of the equipment used to measure energy expenditure has had any effect upon intake. Accordingly, this factor has been omitted in Table $2 \mathrm{~B}$ which gives the remainder of the analysis of variance relating to variability from day to day within subjects. This analysis suggested that there were consistent differences between the days of the week and that these differences did not have the same pattern at the different centres; therefore subsequent analyses were done separately for the six centres.

Table 2. Analyses of variance of energy intake (expressed as $\left.(k c a l / d) \times 10^{-2}\right)$ at centres $A, B$ and $C$

df Mean square

(A) Between subjects

$\begin{array}{lrr}\text { Between centres } & 2 & 87 \mathrm{I} \cdot 88 \\ \text { Exp. } v \text {. non-Exp. (E) } \dagger & \mathrm{I} & 149 \cdot 3 \circ \\ \text { Centre } \times \mathrm{E} & 2 & 142 \cdot 28 \\ \text { Residual } & 28 & 309 \cdot 8 \mathrm{I}\end{array}$

(B) Within subjects

Day of the week (D)

$D \times$ centre

Weeks within centres (W)

$\mathrm{D} \times \mathrm{W}$

Residual

$\begin{array}{rl}6 & 221 \cdot 46 * * \\ 12 & 169 \cdot 47^{* *} \\ 6 & 771 \cdot 20^{* *} \\ 36 & 178 \cdot 20^{* * *} \\ 618 & 48 \cdot 88\end{array}$

$\uparrow$ Contrast between subjects who wore apparatus for measuring energy expenditure (Exp.) and those who did not (non-Exp.).

** $P<0.01$

Table 3. Analyses of variance of energy intake (expressed as $($ kcal $\left./ d) \times 10^{-2}\right)$ at six centres

\begin{tabular}{|c|c|c|c|c|c|c|}
\hline \multirow[t]{2}{*}{ No. of subjects } & \multicolumn{2}{|c|}{$\begin{array}{c}\text { Centre A } \\
\text { 10 }\end{array}$} & \multicolumn{2}{|c|}{$\underset{\mathrm{I} 2}{\text { Centre }} \mathrm{B}$} & \multicolumn{2}{|c|}{$\begin{array}{c}\text { Centre C } \\
12\end{array}$} \\
\hline & df & $\begin{array}{l}\text { Mean } \\
\text { square }\end{array}$ & df & $\begin{array}{l}\text { Mean } \\
\text { square }\end{array}$ & df & $\begin{array}{l}\text { Mean } \\
\text { square }\end{array}$ \\
\hline Days of the week (D) & 6 & $232 \cdot 60$ & 6 & $277 \cdot 6 \mathrm{I}$ & 6 & 50.19 \\
\hline Weeks (W) & 2 & $2030 \cdot 29$ & 2 & I I 35 & 2 & $171 \cdot 95$ \\
\hline $\mathrm{D} \times \mathrm{W}$ & 12 & $304 \cdot 43^{* * *}$ & 12 & $176 \cdot 3^{8 * *}$ & I2 & $53 \cdot 79$ \\
\hline Residual & ז 80 & $59 \cdot 49$ & 220 & $46 \cdot 82$ & 220 & $42 \cdot 25$ \\
\hline No. of subjects & \multicolumn{2}{|c|}{$\begin{array}{c}\text { Centre D } \\
12\end{array}$} & \multicolumn{2}{|c|}{$\begin{array}{c}\text { Centre E } \\
7\end{array}$} & \multicolumn{2}{|c|}{$\begin{array}{c}\text { Centre F } \\
6\end{array}$} \\
\hline & df & $\begin{array}{c}\text { Mean } \\
\text { square }\end{array}$ & df & $\begin{array}{c}\text { Mean } \\
\text { square }\end{array}$ & $\mathrm{d} \mathbf{f}$ & $\begin{array}{l}\text { Mean } \\
\text { square }\end{array}$ \\
\hline Days of the week (D) & 6 & $362 \cdot 79$ & 5 & 103.44 & 5 & $325 \cdot 64 * *$ \\
\hline Weeks (W) & 2 & $707 \cdot 77$ & 2 & 914.18 & 2 & $97 \cdot 85$ \\
\hline $\mathrm{D} \times \mathrm{W}$ & $x x$ & $196.71 * *$ & 9 & 50.84 & 10 & $5 x \cdot 32$ \\
\hline Residual & 207 & $60 \cdot 64$ & 96 & 35.58 & 85 & $29 \cdot 76$ \\
\hline
\end{tabular}

The $\mathrm{D} \times \mathrm{W}$ mean squares are compared with the residual mean squares: the $\mathrm{D}$ mean squares are compared with $\mathrm{D} \times \mathrm{W}$ mean squares.

** $P<0.01$. 
Table 3 gives the within-subject analyses of variance of intake at each of the six centres. The interaction mean square was greater than the residual mean square at all six centres, significantly so $(P<0.01)$ at three of them. This finding indicates that intakes tended to be consistently high or low on a particular day for all subjects at a centre-presumably because the subjects would be following much the same pattern of exercise and would be offered the same choice of food in their canteens.

Table 4. Mean energy intakes (kcal/subject) by day of the week at six centres

\begin{tabular}{|c|c|c|c|c|c|c|c|c|c|}
\hline Centre & $\begin{array}{c}\text { No. of } \\
\text { men }\end{array}$ & Mon. & Tue. & Wed. & Thur. & Fri. & Sat. & Sur. & SE \\
\hline A & IO & 3510 & 3890 & 4280 & 4060 & 4110 & 4030 & 4360 & 318 \\
\hline B & 12 & 4030 & 3420 & 4190 & 3480 & 3760 & 3830 & 39 Iо & 222 \\
\hline C & 12 & 4210 & 3990 & 4210 & 4340 & 4230 & 4050 & 4160 & 122 \\
\hline D & 12 & $355^{\circ}$ & 3560 & 3690 & 4090 & 3980 & 3240 & $3220^{*}$ & 234 \\
\hline $\mathrm{E}$ & 7 & 3170 & $3^{6} 3^{\circ}$ & 3320 & 3400 & $335^{\circ}$ & $2870^{*}$ & 一 & I 55 \\
\hline $\mathrm{F}$ & 6 & 4120 & 3600 & 4410 & 4770 & 3790 & 4010 & - & 169 \\
\hline
\end{tabular}

The means are based on 3 weeks, except those marked with an asterisk which are based on 2 weeks only. The mean of the missing week has been allowed for in calculating the value quoted.

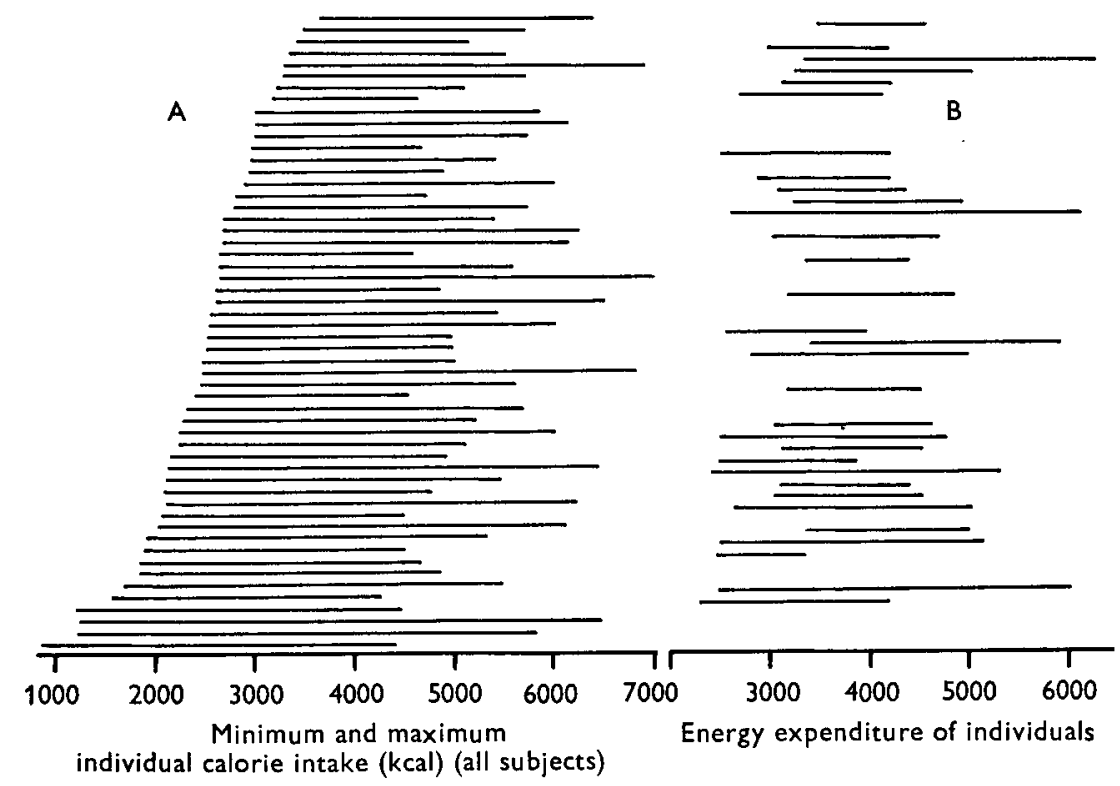

Fig. I. A, the range of energy intake of fifty-five subjects; B, the range of energy expenditure of thirty-one subjects.

In view of the raised interaction mean squares, it is appropriate to use these as 'error' terms when considering the days of the week. Apart from centre F, there was little evidence of a consistent pattern of daily intakes as between the 3 weeks at a given centre. In particular, there was no marked tendency for intake to be especially high or low at week-ends (though Sundays were not studied at centres E and F). Centre F did show a consistent pattern, with low intakes on Tuesdays and Fridays and high 
intakes on Wednesdays and Thursdays. Centre $\mathrm{F}$ was the only centre operating a self-service cafeteria-style canteen, but no obvious reason presents itself for the daily pattern. The daily mean intakes are shown in Table 4.

There were substantial week-to-week differences in average intake at certain centres, but no consistent pattern from centre to centre emerged.

There was an average daily intake of $385^{\circ} \mathrm{kcal}(16 \mathrm{I} 10 \mathrm{~kJ})$ for 1187 man days; the spread of individual intake is illustrated in Fig. I.

There was an average daily intake of $96.6 \mathrm{~g}$ (SD 20.5 ) protein, $148.8 \mathrm{~g}$ (SD $34 \cdot 2$ ) fat, and $564 \mathrm{~g}$ (SD 115 ) carbohydrate, so $10 \%$ of total calories were obtained from protein, $35.5 \%$ from fat and $54.5 \%$ from carbohydrate. There was a wide inter- and intraindividual variation in the daily intake of the three components, as would be predicted from the variation in calorie intake.

The daily intake of alcohol averaged $5.5 \mathrm{~g}$, although most of the alcohol was consumed on Saturday night when the average intake was $22 \mathrm{~g}$.

\section{Plate waste}

The mean daily plate waste was $220 \mathrm{kcal}(920 \mathrm{~kJ})$. There was considerable variation between individuals and between different depots. The average composition of the daily plate waste was $7 \cdot 1 \mathrm{~g}$ protein, $9 \cdot 15 \mathrm{~g}$ fat, $28 \cdot 8 \mathrm{~g}$ carbohydrate, so the proportion wasted of the food on the plate was $7 \%$ protein, $6 \%$ fat and $5 \%$ of the carbohydrate.

\section{Energy expenditure}

Table 5 gives the analysis of variance within subjects for energy expenditure. Again the interaction mean squares were always greater than the residual mean squares, significantly so $(P<0.01)$ at four centres. As noted, this would be expected in view of the common pattern of activity imposed upon men at the same centre on a particular day.

The day-to-day pattern was significantly consistent from week-to-week at centres $A$ and B. The day means are shown in Table 6 and it is clear that (again as expected) the Sunday expenditure was low at each centre. The same is true at centre $C$; although the days mean square in Table 5 is far from significant, the difference between Sunday and the rest of the week at this centre $(369 \pm 182 \mathrm{kcal})$ is just twice its standard error. The absence of a significant pattern at the other three centres is explained by the fact that Sundays were not studied there.

It may be noted that the residual variability of the expenditures was considerably smaller than that of the intakes at all six centres. The average daily energy expenditure was $3750 \mathrm{kcal}(15690 \mathrm{~kJ})(n=609)$ and the average food intake of these subjects was $4010 \mathrm{kcal}(16780 \mathrm{~kJ})$. The spread of individual energy expenditure is shown in Fig. I.

\section{Specific tasks}

Although the measurements of energy expenditure were, in general, made over particular periods of time rather than of particular activities, a number of determinations were made of the energy cost of tasks peculiar to the soldier. In addition, since 
Table 5. Anlayses of variance of energy expenditure (expressed as $\left.(k c a l / d) \times 10^{-2}\right)$ at six centres

\begin{tabular}{|c|c|c|c|c|c|c|}
\hline \multirow[t]{2}{*}{ No. of subjects } & \multicolumn{2}{|c|}{$\begin{array}{c}\text { Centre A } \\
5\end{array}$} & \multicolumn{2}{|c|}{$\begin{array}{c}\text { Centre B } \\
6\end{array}$} & \multicolumn{2}{|c|}{$\begin{array}{c}\text { Centre C } \\
6\end{array}$} \\
\hline & df & $\begin{array}{l}\text { Mean } \\
\text { square }\end{array}$ & df & $\begin{array}{l}\text { Mean } \\
\text { square }\end{array}$ & df & $\begin{array}{c}\text { Mean } \\
\text { square }\end{array}$ \\
\hline Days of the week (D) & 6 & $656 \cdot 72 * *$ & 6 & $165.72 * *$ & 6 & $72 \cdot 10$ \\
\hline Weeks (W) & 2 & $102 \cdot 50$ & 2 & $91 \cdot 56$ & 2 & $70 \cdot 01$ \\
\hline $\mathrm{D} \times \mathrm{W}$ & 12 & $62 \cdot 64 * *$ & 12 & $25 \cdot 47$ & 12 & $5 I \cdot 54 * *$ \\
\hline Residual & 80 & $14 \cdot 27$ & 100 & I7'95 & 100 & $9 \cdot 65$ \\
\hline \multirow[t]{2}{*}{ No. of subjects } & \multicolumn{2}{|c|}{$\begin{array}{c}\text { Centre D } \\
6\end{array}$} & Centre $\mathbf{E}$ & re $\mathbf{E}$ & & $\mathrm{re} F$ \\
\hline & df & $\begin{array}{l}\text { Mean } \\
\text { square }\end{array}$ & $\mathrm{df}$ & $\begin{array}{l}\text { Mean } \\
\text { square }\end{array}$ & df & $\begin{array}{c}\text { Mean } \\
\text { square }\end{array}$ \\
\hline Days of the week (D) & 5 & $53 \cdot 69$ & 5 & $30 \cdot 10$ & 5 & $2 I \cdot 68$ \\
\hline Weeks (W) & 2 & $124 \cdot 27$ & 2 & $50 \cdot 22$ & 2 & $I \cdot 26$ \\
\hline $\mathrm{D} \times \mathrm{W}$ & Io & $62 \cdot 85^{* *}$ & 10 & $25 \cdot 3 x$ & 10 & $4 I \cdot 10^{* * *}$ \\
\hline Residual & 85 & $8 \cdot 68$ & 34 & $14 \cdot 72$ & 68 & $4 \cdot 71$ \\
\hline
\end{tabular}

The $\mathrm{D} \times \mathrm{W}$ mean squares are compared with the residual mean squares: the $\mathrm{D}$ mean squares are compared with the $\mathrm{D} \times \mathrm{W}$ mean squares.

*** $P<0.01$.

Table 6. Mean energy expenditures (kcal/subject) by day of the week at six centres No. of

Centre men Mon. Tue. Wed. Thur. Fri. Sat. Sun. SE

$\begin{array}{llllllllll}\text { A } & 5 & 4480 & 4730 & 4210 & 4160 & 4800 & 3740 & 2890 & 204 \\ \text { B } & 6 & 3370 & 3470 & 3190 & 3490 & 3410 & 3880 & 2890 & 119 \\ \text { C } & 6 & 3800 & 3540 & 3700 & 3780 & 3970 & 3580 & 3360 & 169 \\ \text { D } & 6 & 3890 & 4230 & 3860 & 4020 & 3790 & 3760 & - & 187 \\ \text { E } & 3 & 3800 & 3920 & 3700 & 3630 & 3880 & 3420 & - & 168 \\ \text { F } & 5 & 3740 & 3670 & 3660 & 3840 & 3920 & 3600 & - & 166\end{array}$

Table 7. Mean energy expenditure of the subjects on specific tasks

Assault course

Boxing bout (ABA Rules)

Boxing bout (fly-weight)

Boxing lesson

Boxing and PT period

Cricket (nets)

Digging trenches

Fieldcraft

Football game

Foot-drill (no rifle)

Rifle drill

PT (gymnasium)

P'T with basket ball

Range duties

Weapon training

Weapon training with

bayonet drill
Energy cost

\begin{tabular}{|c|c|c|c|c|c|}
\hline \multirow{3}{*}{$\begin{array}{l}\text { No. } \\
\text { of } \\
\text { sub- } \\
\text { jects }\end{array}$} & \multirow{3}{*}{$\begin{array}{c}\text { No. } \\
\text { of } \\
\text { experi- } \\
\text { ments }\end{array}$} & \\
\hline & & \multicolumn{2}{|c|}{$\mathrm{kcal} / \mathrm{min}$} & \multicolumn{2}{|c|}{$\mathrm{kcal} / \mathrm{kg} \min$} \\
\hline & & Mean & SD & Mean & SD \\
\hline 12 & I9 & $6 \cdot 50$ & $I \cdot 56$ & 0.099 & 0.025 \\
\hline 3 & 3 & $9 \cdot 80$ & $\mathrm{I} \cdot 50$ & 0.143 & 0.022 \\
\hline I & I & 10.41 & - & 0.169 & - \\
\hline 6 & 6 & 3.70 & 0.65 & 0.058 & 0.009 \\
\hline 5 & 5 & $6 \cdot 10$ & 0.37 & 0.092 & 0.005 \\
\hline 6 & 8 & $5 \cdot 75$ & $I \cdot 40$ & 0.092 & 0.038 \\
\hline 29 & 54 & 4.75 & I'35 & 0.071 & 0.025 \\
\hline 14 & 18 & $3 \cdot 65$ & $I \cdot 68$ & 0.056 & 0.026 \\
\hline 5 & 5 & $7 \cdot 80$ & $I \cdot 30$ & 0.120 & 0.022 \\
\hline 30 & 94 & $4 \cdot 85$ & $I \cdot 80$ & 0.075 & 0.028 \\
\hline 26 & 95 & $4 \cdot 10$ & $I \cdot 20$ & 0.064 & 0.020 \\
\hline 24 & 108 & $5 \cdot 95$ & $I \cdot 90$ & 0.091 & 0.033 \\
\hline $\begin{array}{r}4 \\
6\end{array}$ & 6 & $\begin{array}{l}5.10 \\
5 \cdot 10\end{array}$ & 0.95 & 0.080 & 0.015 \\
\hline 27 & 137 & $3 \cdot 10$ & 0.89 & 0.050 & 0.015 \\
\hline 26 & 87 & 4.10 & $1 \cdot 78$ & 0.064 & 0.030 \\
\hline 13 & 21 & 445 & 0.66 & 0.069 & O.01 I \\
\hline
\end{tabular}

Weight of subjects (kg)

$\begin{array}{cc}\text { Mean } & \text { sD } \\ 65 \cdot 81 & 5 \cdot 61 \\ 68 \cdot 57 & 2 \cdot 01 \\ 61 \cdot 57 & - \\ 63 \cdot 62 & 4 \cdot 83 \\ 66 \cdot 26 & 3 \cdot 67 \\ 62 \cdot 44 & 5 \cdot 79 \\ 67 \cdot 30 & 3 \cdot 85 \\ 64 \cdot 98 & 7 \cdot 33 \\ 65 \cdot 18 & 7 \cdot 68 \\ 64 \cdot 56 & 5 \cdot 59 \\ 64 \cdot 33 & 6 \cdot 70 \\ 65 \cdot 50 & 6 \cdot 94 \\ 63.62 & 4 \cdot 83 \\ 62 \cdot 20 & 4 \cdot 89 \\ 64 \cdot 39 & 7 \cdot 04 \\ 64 \cdot 77 & 7 \cdot 37\end{array}$


Table 8. Average time (min/d) spent on indoor and outdoor activities at the different depots

Indoor activities

Ablutions

Blancoing

Bed-making

Bumping

Cleaning rifle

Dancing

Dressing

Floor sweeping

Ironing

Kneeling

Laying out kit

Lying

Peeling potatoes

Polishing sitting

Polishing standing

Polishing kneeling

Shuffling

Sitting

Sitting manipulating

Scrubbing

Sleeping

Stairs

Standing

Table-tennis

Snooker

Darts

Window cleaning

Total

Outdoor activities

Assault course

Basket ball

Boxing

Chopping wood

Climbing

Crawling

Cricket

Cycling

Digging

Drill

Driving

Endurance marching

Football

Heavy manual work

Jumping

Kneeling manipulating

Lying manipulating

Marching

Painting

PT

Riding

Rifle drill

Running

Sitting alert

Skating

Centre

\begin{tabular}{|c|c|c|c|c|}
\hline A & B & C & D & $\mathrm{E}$ \\
\hline $24 \cdot 6$ & 25.0 & $28 \cdot 4$ & $23 \cdot 3$ & $12 \cdot 2$ \\
\hline $7 \cdot 5$ & $3 \cdot 3$ & 20.7 & $7 \cdot 1$ & $9 \cdot \mathbf{I}$ \\
\hline 15.0 & $\begin{array}{l}16.7 \\
\end{array}$ & 17.8 & $15 \cdot 1$ & 15.2 \\
\hline 0.8 & 3.9 & $I_{4} \cdot 4$ & $I \cdot I$ & 0.5 \\
\hline 13.9 & $\mathrm{I} \cdot 3$ & $12 \cdot 0$ & $7 \cdot 9$ & $3 \cdot 6$ \\
\hline $2 \cdot 2$ & 0.4 & 0.6 & 0.5 & 0.3 \\
\hline $3^{8} \cdot 6$ & $23^{\circ}$ & $36 \cdot 8$ & $26 \cdot 3$ & $21 \cdot 5$ \\
\hline 4.9 & 10.7 & 12.0 & $3 \cdot 2$ & 30 \\
\hline 3.5 & $2 \cdot I$ & $3 \cdot 8$ & $2 \cdot 6$ & 1.5 \\
\hline 0.4 & 3.7 & $4 \cdot 2$ & 0.7 & 0.5 \\
\hline 0.8 & - & - & - & - \\
\hline $30 \cdot 3$ & $44 \cdot 3$ & $7 \cdot 2$ & $56 \cdot 0$ & $53^{\circ} \circ$ \\
\hline $3 \cdot 3$ & 0.9 & - & - & - \\
\hline $34 \cdot 2$ & $69 \cdot 9$ & $96 \cdot 9$ & $72 \cdot 5$ & $26 \cdot 8$ \\
\hline II 9 & 10.2 & $4 \cdot 5$ & $4 \cdot 5$ & 0.6 \\
\hline 0.9 & $x \cdot I$ & 1.6 & 0.3 & - \\
\hline $26 \cdot 4$ & $37 \cdot 4$ & $19 \cdot 0$ & 36.4 & $44^{\cdot} \cdot 6$ \\
\hline $298 \cdot \mathrm{I}$ & $304 \cdot 0$ & $265 \cdot 7$ & $223 \cdot I$ & 203.7 \\
\hline$I \cdot 2$ & $5 \cdot 2$ & $20 \cdot \mathrm{I}$ & $40 \cdot 3$ & 146.6 \\
\hline $3^{3} \cdot \mathrm{I}$ & $3 \cdot I$ & 0.5 & $\mathrm{I} \cdot 7$ & 0.4 \\
\hline $421 \cdot 7$ & 497.5 & 405.5 & $427 \cdot 2$ & $439 \cdot 8$ \\
\hline $2 \cdot 5$ & $9 \cdot 6$ & $5^{\circ} 0$ & 3.5 & $0 \cdot I$ \\
\hline 148.6 & 150.9 & 167.0 & 175.8 & $158 \cdot 3$ \\
\hline- & - & $\mathrm{I} \cdot 5$ & - & $I \cdot 3$ \\
\hline- & $1 \cdot 3$ & 0.4 & - & - \\
\hline- & 2.6 & - & - & - \\
\hline 一 & - & 0.1 & - & - \\
\hline 1094.4 & $I 228 \cdot I$ & I $132 \cdot 7$ & II $29^{\circ} \mathrm{I}$ & $1142 \cdot 6$ \\
\hline
\end{tabular}

$2 \cdot 3$

-

0.5
0.8

I. 6

$-$

$26 \cdot 5$

$49 \cdot 1$

$\overline{8 \cdot 7}$

Ir. 5

$2 \cdot 8$

0.8

$2 \cdot 4$

$27 \cdot 1$

$\overline{4 \cdot 6}$

-

10.4
10.9

-

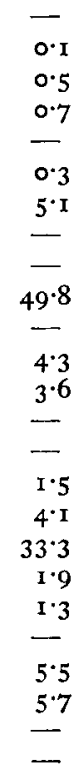

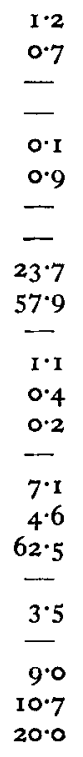

\begin{tabular}{|c|c|c|}
\hline- & & 0 \\
\hline 0.4 & & $\mathrm{I}^{\circ}$ \\
\hline- & & \\
\hline- & & - \\
\hline 0.2 & & 0 \\
\hline- & & \\
\hline 0.3 & & - \\
\hline- & & - \\
\hline $50^{\circ} 9$ & & 50 \\
\hline & & 4 \\
\hline $\begin{array}{l}0.1 \\
I .0\end{array}$ & & \\
\hline I.0 & & \\
\hline$\overline{0}$ & & 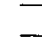 \\
\hline$I \cdot 9$ & & \\
\hline $5^{\cdot I}$ & & 9 \\
\hline 63.7 & & 29 \\
\hline- & & \\
\hline $\begin{array}{l}7.4 \\
0.2\end{array}$ & & \\
\hline $4^{\circ} 0$ & & \\
\hline 8.8 & & \\
\hline$\overline{-}$ & & \\
\hline
\end{tabular}


Table 8 (cont.)

Outdoor activities

Squatting

Standing manipulating

Step test

Tennis

Walking

Walking + load

Wrestling

Total

\begin{tabular}{rrrrr}
\multicolumn{1}{c}{ A } & B & \multicolumn{1}{c}{ C } & D & E \\
2.5 & 3.3 & $\mathrm{I} \cdot 9$ & 0.7 & - \\
$48 . \mathrm{I}$ & 5.8 & 35.3 & $56 . \mathrm{I}$ & $\mathrm{I0I} \cdot 9$ \\
0.8 & 0.6 & 0.6 & 0.5 & $\mathrm{I} \cdot 6$ \\
- & 0.8 & - & - & - \\
127.3 & 82.8 & 64.2 & 109.8 & 80.7 \\
7.6 & 0.4 & 2.4 & 0.1 & - \\
- & 0.9 & - & - & - \\
346.3 & 212.3 & 308.0 & 311.3 & 297.3
\end{tabular}

Table 9. Mean energy expenditure on quick marching (sixteen subjects)

$\begin{array}{lrc}\text { Mean expenditure } & \text { Week I } & \text { Week 2 } \\ \mathrm{kcal} / \mathrm{min} & 7.59 & 7.17 \\ \mathrm{SD} & 1.64 & 1.56 \\ \mathrm{kcal} / \mathrm{kg} \mathrm{min} & 0.120 & 0.109 \\ \mathrm{SD} & 0.025 & 0.026 \\ & \text { Week I-week 2 } & \text { NS }(P>0.05) . \\ & \text { Week 2-week 3 } & \text { NS }(P>0.05) \text {. } \\ & \text { Week I } \rightarrow \text { week 3 } & \text { Significant }(P<0.05) \text {. }\end{array}$

The significance of differences applies to both $\mathrm{kcal} / \mathrm{min}$ and $\mathrm{kcal} / \mathrm{kg} \mathrm{min}$. NS, not significant.

the wearing of the IMP did not appreciably interfere with activity, it was possible to make measurements during various games, and even boxing was studied as one of the subjects at a depot was a champion boxer. The results of these various measurements are given in Table 7. The details of the time spent in various activities are shown in Table 8, which also includes particulars of the time spent indoors and outdoors.

The energy cost of marching, a characteristic army activity, was studied in some detail and measurements were made during a carefully standardized drill in each week of the recruits' training. The results summarized in Table 9 show that there was. a small but significant drop in the energy cost of marching between the first and the last weeks of the surveys, as the recruits became more skilled.

\section{Relationship between energy expenditure and food intake}

It remains to consider the relationship between intake and expenditure and this may be done on several time scales. Total energy intake over 3 weeks may be related to the total expenditure over the same period. Expenditure was notably lower on Sundays; accordingly, the correlation has been evaluated within centres and pooled separately for centres A-C (at which Sunday figures were available) and for centres D-F. At centres A-C the correlation coefficient was $+0.788(P \sim 0.001)$ while at centres $\mathrm{D}-\mathrm{F}$ the correlation was only $+0.083(P>0.5)$. This curious situation is illustrated in Fig. 2, which also shows that (apart from centre A) many of the estimated intakes were considerably higher than the corresponding expenditures. The correlation coefficient for centres A-C is practically unchanged if the Sunday results are not used 
at these centres. However, Fig. 2 shows that the high correlation is misleading, in that the relation between intake and expenditure, at least at centres $B$ and $C$, was far from one of equality.

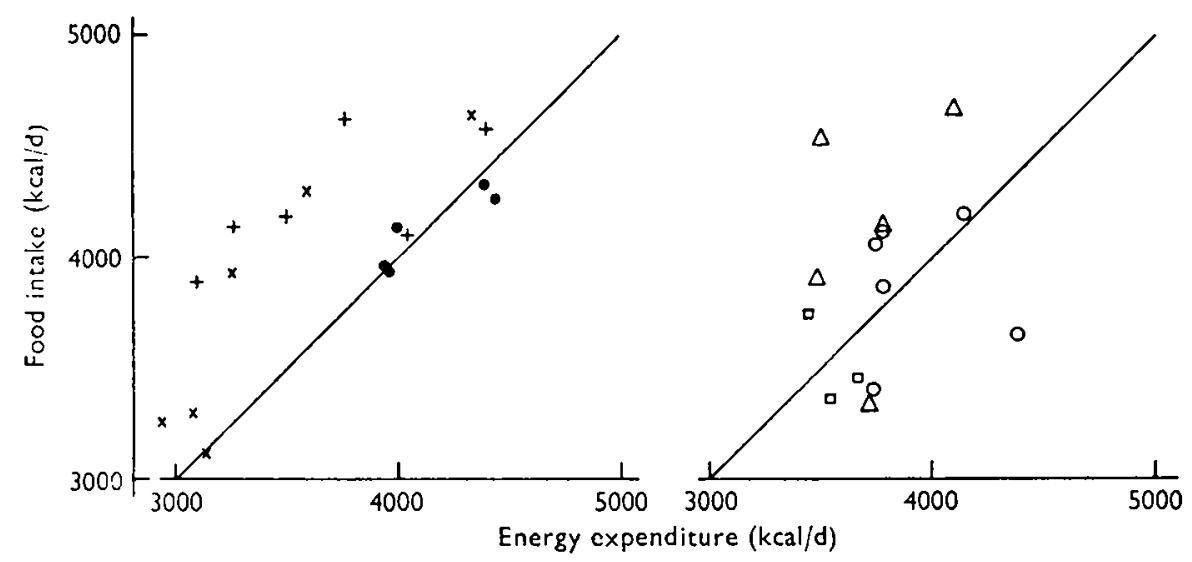

Fig. 2. Relationship between energy expenditure and food intake of subjects at each centre for the total period of the survey. , subjects at centre $A ; \times$, at $B ;+$, at $C ; O$, at $D ; \square$, at $E$; $\triangle$, at $\mathbf{F}$.

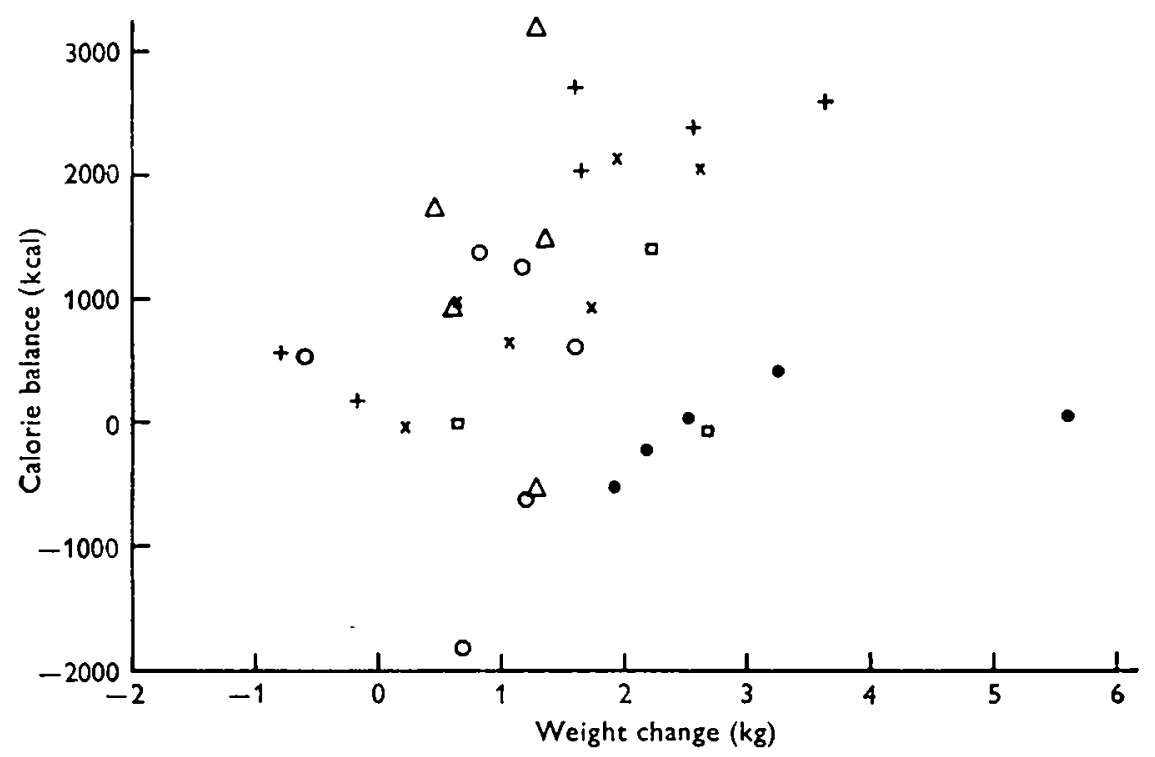

Fig. 3. Relationship between calorie balance and body-weight change of subjects at each centre for the total period of the survey. $O$, subjects at centre $A ; \times$, at $B ;+$, at $C ; O$ at $D$; $\square$, at $\mathbf{E} ; \triangle$, at $\mathbf{F}$.

The mean calorie balance over 3 weeks has been related to the total weight change during the period of observation, and the results are shown in Fig. 3. There is a suggestion of heterogeneity in this figure; most subjects gained in weight and this gain was associated with a positive calorie balance, but nine subjects (including all 
those at centre A) gained a good deal more than their calorie balance would seem to justify.

Daily weight change and daily calorie intake were significantly related $(n=86 \circ$, $r=0.295, P<0.001)$ and there was also a significant negative relationship between daily weight change and daily energy expenditure $(n=430, r=-0.297, P<0.001)$.

There was a significant negative correlation between calorie balance for $5^{-7} \mathrm{~d}$ and body-weight $(n=89, r=-0.32, P<0.01)$.

Table 10. Serial correlations of energy intake and expenditure (Exp.)

\begin{tabular}{|c|c|c|c|}
\hline \multirow[b]{2}{*}{$\begin{array}{l}\text { No. of days } \\
(n)\end{array}$} & \multicolumn{3}{|c|}{ Correlation coefficient } \\
\hline & $\begin{array}{c}\text { Intake with intake } \\
n \text { days later }\end{array}$ & $\begin{array}{l}\text { Exp. with Exp. } \\
n \text { days later }\end{array}$ & $\begin{array}{l}\text { Exp. with intake } \\
n \text { days later }\end{array}$ \\
\hline \multicolumn{4}{|c|}{ (a) Day means at each centre } \\
\hline ० & $I \cdot \infty$ & $I \cdot 00$ & -0.13 \\
\hline I & -0.13 & -0.19 & -0.03 \\
\hline 2 & -0.38 & -0.10 & 0.00 \\
\hline 3 & +0.02 & +0.18 & -0.16 \\
\hline \multicolumn{4}{|c|}{ (b) Departures from day means } \\
\hline$\circ$ & $r \cdot \infty$ & $\mathrm{I} \cdot \infty 0$ & +0.05 \\
\hline I & -0.06 & -0.03 & +0.10 \\
\hline 2 & -0.06 & -0.01 & +0.03 \\
\hline 3 & -0.05 & -0.07 & 0.00 \\
\hline
\end{tabular}

Table I I. High and low energy intake and expenditure by the subjects

Days of highest expenditure

Days of lowest expenditure

Days of highest intake

Days of lowest intake

$\begin{array}{cccc}\begin{array}{c}\text { Intake exceeds } \\ \text { expenditure }\end{array} & \begin{array}{c}\text { Expenditure } \\ \text { exceeds intake }\end{array} & \begin{array}{c}\text { Mean } \\ \text { expenditure } \\ (\mathrm{kcal})\end{array} & \begin{array}{c}\text { Mean } \\ \text { intake } \\ (\mathrm{kcal})\end{array} \\ \text { 30 occasions } & 69 \text { occasions } & 4400 & 3960 \\ 8 \text { I occasions } & \text { I8 occasions } & 3 \times 60 & 3990 \\ 94 \text { occasions } & 5 \text { occasions } & 3730 & 4930 \\ \text { I I occasions } & 88 \text { occasions } & 375^{\circ} & 2980\end{array}$

Further analysis aimed at studying the weekly totals of intake and expenditure. The calorie balance for each week was expressed as a deviation from the subject's average figure for the 3 weeks, and then related to the change in weight over the same week expressed in the same terms. The weight changes were assessed by fitting straight lines to the seven daily values for each week to reduce the effects of day-to-day fluctuations. The resulting correlations were $0.4 \mathrm{I} 6$ for centres A-C $(P \sim .0 .02)$ and $0.34 \mathrm{I}$ for centres D-F $(P \sim 0.15)$, averaging 0.403 . It appears that a rather small amount of the week-to-week calorie balance variation in a subject can be explained by contemporary changes in weight.

In studying the day-to-day effects, the intakes and expenditures of the different subjects at one centre cannot be considered independent so that serial auto- and crosscorrelations were calculated first from the day means at each centre (omitting Sunday) and next for each subject's departures from these day nueans. The first set of correlations relates to questions such as 'If the men at this centre collectively show a high 
expenditure on day $x$, do they tend to show a high intake on day $x+I$ ?', while the second relates rather to questions such as 'If this subject has a high expenditure relative to his fellows on day $x$, does he tend to have a high intake (also relative to his fellows) on day $x+1$ ?' Correlations were calculated for each centre separately and averaged over centres. The results are shown in Table ro. All the correlations were very small. Taking a centre as a whole, there was a slight tendency for a day of high intake to be followed by $\mathrm{I}$ or 2 days of low intake, and to a lesser extent the same is true for expenditure. There appears to be no detectable pattern of relationship between expenditures and the intakes during the same and following days. The subjects' departures from the means for their centre were effectively uncorrelated on a day-today basis.

On many occasions it appeared that on days of high energy expenditure food intake was depressed. This idea has been tested by examining for each individual the food intake on the days of the highest and the lowest expenditure in each week. The results are summarized in Table I I.

\section{Body-weight}

The positive relationship between body-weight and food intake for I week was not statistically significant $(n=167, r=0.127, P>0.05)$. The statistically significant relationship between body-weight and energy expenditure $(n=84, r=0.699$, $P<0.001$ ) was in part due to the use of body-weight or surface area to calculate the energy expenditure for some tasks (see p. ro95). When a comparison was made between body-weight and the measured energy expenditure in groups of subjects doing similar tasks (e.g. marching) a wide scatter was obtained. In the marching study already mentioned the correlation between body-weight and energy expenditure was low and not significant.

\section{DISCUSSION}

The absence of any evident relationship between daily food intake and the energy expenditure on the same day has been observed in previous surveys of young men (Edholm et al. I955) and similar surveys of young women (Durnin et al. 1957). Durnin (I96I) has examined the results of a number of surveys and concluded that 'the results make it unlikely that most of the current theories in the control of "appetite" can be directly applied to man.' He criticized the suggestion made by Edholm et al. (1955) that there was a lag of $2 \mathrm{~d}$ between energy expenditure and food intake.

The results reported in the present paper illustrate the difficulty of establishing the relationship between energy expenditure and food intake. It is clear that there are many factors which could influence the relationship, including the appetite centres which have been demonstrated to exist in the hypothalamic region (Anand, I96I) and the ways in which these centres may be affected by the concentration of various metabolites. The information obtained in the present study has been used to examine the temporal relationships as well as the possible influence of body-weight and basal metabolic rate.

There was a significant correlation between intake and expenditure when the combined results for all the subjects for the three separate weeks of study were compared. 
However, there were considerable differences between centres and the correlation was high for centres $\mathrm{A}, \mathrm{B}$ and $\mathrm{C}$ but not for $\mathrm{D}, \mathrm{E}$ and $\mathrm{F}$. The fact that the subjects as a whole gained weight (average gain over approximately 8 weeks was $\mathrm{I} \cdot 5 \mathrm{~kg}$ ) is consistent with the average excess of intake over expenditure but does not account for the apparent differences between the results at centres $\mathrm{A}, \mathrm{B}$ and $\mathrm{C}$ compared with $\mathrm{D}, \mathrm{E}$ and $\mathrm{F}$.

There was no evident reason to account for the apparent differences between the results for the first three and the last three centres. During the ist week at centre A, which was the first to be studied, all the subjects had very large weight increases which were more than could be accounted for by an excess of intake over expenditure. It is possible the subjects had lost considerable body water through cold diuresis in the days immediately before the study began, as there had been a sharp fall in temperature and the weather when the survey started was extremely cold.

A good agreement between intake and expenditure has been found in several surveys continued for periods of $6 \mathrm{~d}$ (Durnin, 1961; Durnin \& Brockway, 1959). The virtual absence of a correlation between daily intake and expenditure contrasts with the significant correlation obtained when $6 \mathrm{~d}$ or more are combined. The suggestion by Edholm et al. (1955) that there was a lag of $2 \mathrm{~d}$ between energy expenditure and food intake is not supported by the autocorrelations obtained in the present study. It is evident that there must be a lag between expenditure and intake but the duration of the lag is variable both between individuals and in the same individual.

Among the factors which might affect the time relationship is the degree of irregularity of energy expenditure. The recruits led a very active life, with an average energy expenditure which was rather higher than that of coal-miners $\left(375^{\circ} \mathrm{kcal}\right.$ compared with 3660 (Garry et al. 1955)), but variation in daily level was large. On exceptionally arduous days, food intake was nearly always substantially less than energy expenditure. But there was no consistent pattern in the way in which the calorie deficit was paid off, partly perhaps because days of high energy expenditure were not consistently followed by low-energy days. The pattern of energy expenditure was so irregular that it has not proved possible to determine if there are longer or shorter delays in making up deficits of varying amounts. Similarly, the effect of a calorie surplus, which was usual on days of low energy expenditure, did not affect in any evident way the size of a deficit incurred on a subsequent arduous day. The lack of relationship between daily intake and expenditure was also demonstrated by the almost identical mean intakes on days of highest and lowest expenditure, and similarly by the identity of mean energy expenditure on days of highest and lowest food intake.

There was a low correlation between body-weight and food intake. Thomson, Billewicz \& Passmore (1961) have reviewed the findings in a number of surveys and have shown how small is the increased intake of food with increase of body-weight, and Garry et al. (1955) drew attention to the low correlation between body-weight and food intake in coal-miners and clerks. Walker (1965) showed that there was no linear correlation between mean daily intake and body-weight in South African students. In view of this substantial evidence, the allowances that are made in FAO recommendations for increased food for heavier subjects need revision. On the other hand, bodyweight and energy expenditure are significantly correlated but, as pointed out above, 
this is in part due to the method for calculating energy expenditure which, for some activities, includes body-weight.

Thomson et al. (196I) state that 'the physiological evidence that extra weight involves extra energy expenditure is incontestable' and conclude that 'heaviness is generally associated with diminished physical activity'. The positive calorie balance, or the excess of intake over expenditure which was found for the subjects as a whole was largest for the lighter subjects and smallest for the heavier subjects. Since the calculation of energy expenditure includes to some extent body-weight, the calorie balance figures will also be affected. However, weight increases were larger amongst lighter subjects, and the heavier the man the smaller the weight gain. This finding supports the conclusion that calorie balance is also related to body-weight. It is probable that in the special case of military training the heavier man is unable to diminish his physical activity, but he still appears to eat less than might be predicted.

Weight changes and calorie balance are significantly related over a period of $24 \mathrm{~h}$, but the correlation is low and there is a wide scatter which is not greatly reduced when the calorie balance for $6 \mathrm{~d}$ is related to the corresponding weight change. The scatter can be attributed to the considerable changes of body water which can markedly affect weight changes over a short period of time (Adam, Best \& Edholm, I96r). For this reason, calculation of the calorie cost of weight change from our results is probably not valid. It is likely that the weight change which was associated with a positive calorie balance during the 3 weeks of measurement was due to increase in muscle mass. The men were continuously engaged in strenuous activities, and in studies of athletes during training it has been shown that there is an increase in muscle mass (Pařízková \& Poupa, 1963). Allen, Krzywicki \& Isaac (1960) studied the changes in body composition of seventy-five soldiers who were offered food ad lib. over a period of $28 \mathrm{~d}$ while continuing with military training. There was an average weight gain of $2.03 \mathrm{~kg}$; the smaller men gained a mixture of protein and fat, but the larger men lost some fat.

A particular difficulty, which has been discussed by Durnin \& Brockway (1959), is to determine the accuracy of the measurement of food intake and energy expenditure, and hence of the calculation of calorie balance. Weight change does not provide an adequate independent check because of changes in body water. The subjects were army recruits, under discipline, so it was possible to have complete observation of their activities throughout the $24 \mathrm{~h}$, a situation which is unusually favourable for studies of energy expenditure and food intake. The army ration was identical in all centres although food preparation did differ, and the subjects' activities in the different depots were also closely similar. It seems reasonable to infer that, in these exceptional circumstances, measurements were made with considerable accuracy. An independent check could only be made by measuring changes in body composition, but current methods have a sizeable error.

It is worth emphasizing again that there was a high degree of uniformity of activity, of food provided, and of environment, and the subjects were closely similar in age. In spite of this, the variations observed in energy expenditure and food intake were strikingly large. 
There were many who assisted in this investigation, including $\mathrm{Dr} H$. E. Lewis and Dr J. G. Fletcher. We had the benefit of the advice of Dr Elsie M. Widdowson, and in the Department of Experimental Medicine under her guidance many samples of food have been analysed. Detailed menus of food sold in the Navy, Army and Air Force Institute (NAAFI) were kindly supplied by members of the Institute. Mrs Pamela Bradbury and Miss Jane Troop carried out many of the statistical analyses.

We also record our grateful thanks to the recruits who volunteered to act as subjects and who co-operated so well, and to the officers and NCO's of the six depots who gave continuous help and assistance. The study was carried out under the auspices of the Army Personnel Research Committee.

\section{REFERENCES}

Adam, J. M., Best, T. W. \& Edholm, O. G. (196r). 7. Physiol., Lond. 156, 38 P.

Allen, T. H., Krzywicki, H. J. \& Isaac, G. J. (1960). Rep. U.S. Army med. Res. Nutr. Lab. no. 243.

Anand, B. K. (196I). Physiol. Rev. 4r, 677.

Consolazio, C. F., Hawkins, J. M., Johnson, O. C. \& Friedemann, T. E. (1959). U.S. arm. Forces med. F. ro, Ir 33 .

Durnin, J. V. G. A. (196r). F. Physiol., Lond. 156, 294.

Durnin, J. V. G. A., Blake, E. C. \& Brockway, J. M. (1957). Br. J. Nutr. II, 85.

Durnin, J. V. G. A. \& Brockway, J. M. (1959). Br. F. Nutr. r3, 4I.

Edholm, O. G., Fletcher, J. G., Widdowson, E. M. \& McCance, R. A. (1955). Br. F. Nutr. 9, 286.

Garry, R. C., Passmore, R., Warnock, G. M. \& Durnin, J. V. G. A. (1955). Spec. Rep. Ser. med. Res. Coun. no. 289.

McCance, R. A. \& Widdowson, E. M. (1960). Spec. Rep. Ser. med. Res. Coun. no. 297.

Pařizková, J. \& Poupa, O. (I963). Br. F. Nutr. 17, 341.

Thomson, A. M., Billewicz, W. Z. \& Passmore, R. (I96r). Lancet. i, 1027.

Walker, S. E. (1965). Br. F. Nutr. r9, I.

Wolff, H. S. (1958). Q. भl exp. Physiol. 43, 270.

Wolf, H. S. (1959). Ergonomics 2, 354. 